ISSN 1678-3921

Journal homepage: www.embrapa.br/pab

For manuscript submission and journal contents, access: www.scielo.br/pab

Diego Baretta(1)

Maicon Nardino ${ }^{(2 \otimes)}$,

Ivan Ricardo Carvalho(1)

Alan Junior de Pelegrin ${ }^{(1)}$,

Mauricio Ferrari( ${ }^{(3)}$,

Victoria Freitas de Oliveira(1)

Vinícius Jardel Szareski(1)

Antonio Costa de Oliveira(1)

Willian Silva Barros ${ }^{(1)}$,

Velci Queiróz de Souza ${ }^{(4)}$ and

Luciano Carlos da Maia ${ }^{(1)}$

(1) Universidade Federal de Pelotas, Faculdade de Agronomia Eliseu Maciel,

CEP 96010-900 Capão do Leão, RS, Brazil.

E-mail: barettadiego@gmail.com,

carvalho.irc@gmail.com,

pelegrinagro@gmail.com

vicdeol@gmail.com,

viniciusszareski@gmail.com,

acostol@terra.com.br,

wsbarros@hotmail.com

lucianoc.maia@gmail.com

(2) Universidade Federal de Viçosa,

Departamento de Fitotecnia, Campus

Universitário, CEP 36570-900 Viçosa, MG,

Brazil. E-mail: nardino@ufv.br

(3) SLC Agrícola, Rua Bernardo Pires,

no $128,4^{\circ}$ andar, Santana, CEP 90620010

Porto Alegre, RS, Brazil.

E-mail: ferraritatu@gmail.com

(4) Universidade Federal do Pampa, Campus São Gabriel, Avenida Antônio Trilha, no 1.847, Centro,

CEP 96450000 São Gabriel, RS, Brazil.

E-mail: velciq@gmail.com

$凶$ Corresponding author

Received

October 27, 2017

Accepted

August 21, 2019

How to cite

BARETTA, D.; NARDINO, M.; CARVALHO,

I.R.; PELEGRIN, A.J. de; FERRARI, M.;

OLIVEIRA, V.F. de; SZARESKI, V.J.; OLIVEIRA,

A.C. de; BARROS, W.S.; SOUZA, V.Q. de;

MAIA, L.C. da. Heterosis and genetic distance

in intervarietal corn hybrids. Pesquisa

Agropecuária Brasileira, v.54, e00265, 2019.

DOI: https://doi.org/10.1590/S1678-3921.

pab2019.v54.00265

\section{Heterosis and genetic distance in intervarietal corn hybrids}

\begin{abstract}
The objective of this work was to evaluate the performance of intervarietal corn (Zea mays) hybrids with topcross crosses between landrace populations, and to confirm whether genetic dissimilarity between populations is correlated with the heterosis of the intervarietal hybrids in the field. Nine topcross hybrids were evaluated with their tester 'BRS Planalto', and the following landrace populations were used as parents: Argentino Branco, Dente de Ouro, Amarelão, Criolão, Caiano Rajado, Branco Oito Carreiras, Branco Roxo Índio, Cateto Branco, and Argentino Amarelo. The tester 'BRS Planalto' and the topcross hybrids Branco Oito Carreiras x 'BRS Planalto' and Criolão $\mathrm{x}$ 'BRS Planalto' showed higher per se potential for grain yield. The topcross hybrid Branco Oito Carreiras x 'BRS Planalto' showed a better performance for number of grains per row, grain weight, and ear diameter, whereas Criolão $\mathrm{x}$ 'BRS Planalto' displayed a better performance for the number of grains per row and ear length. Greater estimates of genetic distance did not necessarily result in greater heterosis values and were exclusively correlated with grain ear length. Therefore, it is not possible to predict the effects of high heterosis on grain yield, based on the genetic distance between the populations involved in the crosses.
\end{abstract}

Index terms: Zea mays, genetic dissimilarity, heterosis, landraces, topcross.

\section{Heterose e distância genética em híbridos intervarietais de milho}

Resumo - O objetivo deste trabalho foi avaliar o desempenho de híbridos de milho (Zea mays) intervarietais, a partir de cruzamentos topcross entre populações crioulas, além de confirmar se a dissimilaridade genética entre as populações é correlacionada à heterose dos híbridos intervarietais no campo. Nove híbridos topcross foram avaliados com seu testador 'BRS Planalto', e as seguintes populações crioulas foram utilizadas como genitores: Argentino Branco, Dente de Ouro, Amarelão, Criolão, Caiano Rajado, Branco Oito Carreiras, Branco Roxo Índio, Cateto Branco e Argentino Amarelo. O testador 'BRS Planalto' e os híbridos topcross Branco Oito Carreiras x 'BRS Planalto' e Criolão x 'BRS Planalto' apresentaram maior potencial per se quanto ao rendimento de grãos. O topcross Branco Oito Carreiras x 'BRS Planalto' apresentou melhor desempenho quanto a número de grãos por fileira, massa de grãos da espiga e diâmetro de espiga, enquanto o Criolão x 'BRS Planalto' apresentou melhor desempenho quanto a número de grãos por fileira $\mathrm{e}$ comprimento de espiga. As maiores estimativas de distância genética não implicaram, necessariamente, altos valores de heterose, e tiveram correlação apenas com o comprimento da espiga. Portanto, não é possível predizer os efeitos de alta heterose sobre o rendimento de grãos, com base na distância genética entre as populações envolvidas nos cruzamentos.

Termos para indexação: Zea mays, dissimilaridade genética, heterose, populações crioulas, topcross. 


\section{Introduction}

Corn breeding programs would greatly benefit from a more comprehensive knowledge of Brazilian corn germplasm, since there is evidence of a great competitiveness in the market for the development of new cultivars (Araújo \& Nass, 2002). Competition assays and germplasm characterization trials represent the majority of studies on corn landrace in Brazil (Paixão et al., 2008; Carpentieri-Pípolo et al., 2010; Coimbra et al., 2010) show great landrace potential, showing similar, or even greater, performance of landraces, in comparison to commercial and hybrid varieties, especially at low-technology cultivation levels.

Heterosis effects on grain yield are commonly sought (Allard, 1971) because they have a great influence on the success of corn hybrids. According to quantitative genetics, the heterosis effects are related to allele frequency in the parents, and the genetic divergence between such parents positively affects them (Falconer \& Mackay, 1996).

Multivariate analysis, such as genetic dissimilarity, are often used to classify genotypes into heterotic groups (Baretta et al., 2016). According to Sudré et al. (2005), studies on genetic dissimilarity are of great importance for breeding programs involving hybridizations, as they provide parameters for the identification of parents that would supply the progeny with greater heterotic effects. The relationship between genetic dissimilarity of landrace populations and heterosis estimates is still poorly studied. The absence of this information has made it difficult to form heterotic groups suitable for the formation of intervarietal hybrids or for the selection of inbred lines in breeding programs (Baretta et al., 2017; Carvalho et al., 2017).

The objective of this work was to evaluate the performance of some intervarietal hybrids, from topcross crosses between corn landrace populations and a broad genetic-based tester, as well as to verify whether the genetic dissimilarity between the populations is correlated with heterosis of the intervarietal hybrids in the field.

\section{Materials and Methods}

The experiment was carried out in the Centro Agropecuário da Palma $\left(31^{\circ} 45^{\prime} \mathrm{S}, 52^{\circ} 29^{\prime} \mathrm{W}\right.$, at $13 \mathrm{~m}$ altitude), in an experimental area belonging to the Universidade Federal de Pelotas, in the municipality of Capão do Leão, in the state of Rio Grande do Sul, Brazil, on an Argissolo Vermelho-Amarelo distrófico, according to Santos et al. (2006), i.e., a Paleudalf soil.

In the 2012/2013 crop season, nine topcross hybrids, obtained from crosses between the 'BRS Planalto' tester and landrace populations were evaluated: Argentino Branco $\times$ 'BRS Planalto', Dente de Ouro $\times$ 'BRS Planalto', Amarelão × 'BRS Planalto', Criolão $\times$ 'BRS Planalto', Caiano Rajado × 'BRS Planalto', Branco Oito Carreiras $\times$ 'BRS Planalto', Branco Roxo Índio $\times$ 'BRS Planalto', Cateto Branco $\times$ 'BRS Planalto', and Argentino Amarelo $\times$ 'BRS Planalto'. The landrace populations were evaluated with the top crosses in the 2013/2014 crop season.

A randomized complete block design, with three replicates, was used. The experimental plots consisted of two $5.0 \mathrm{~m}$ rows, with 42 plants per plot (with $0.70 \mathrm{~m}$ spacing between rows), corresponding to the density of 60,000 plants ha $^{-1}$. Cultural traits were performed in accordance with the recommendations for the culture in the region.

The following traits were evaluated: leaf angle (LA), obtained with the first leaf below the first ear, in three plants; number of tassel branches (NT); height of ear insertion (EH); plant height (PH) from soil surface up to the last leaf node of the plant; ear diameter (ED), measured in the central part of three ears; number of grains per ear (NG); number of grain per row (NGR); grain mass per ear (GM); ear mass (EM); ear length (EL); prolificacy (PROL), which refers to the relation between total of ears per total of plants in the plot; 100-grain mass (HGM); and grain yield (GY) per plot, corrected to $13 \%$ moisture.

Data were subjected to the analysis of variance for the genitor populations and their topcross hybrids. Heterosis estimates were performed based on the model (Falconer \& Mackay 1996).

The genetic dissimilarity between the genitor populations was estimated using the generalized distance of Mahalanobis $\left(\mathrm{D}^{2}\right)$, with data from the means of the genotypes and the residual covariance matrix, according to Cruz et al. (2012). The UPGMA grouping method was used to form the dendrogram. In order to verify the fit between the dissimilarity matrix and the dendrogram, the cophenetic correlation coefficient (r) (Sokal \& Rohlf, 1962) was calculated 
with the NTSYS program (Rohlf, 2000). The Pearson's correlation coefficient between genetic dissimilarity and heterosis estimates was evaluated for the different characters, using the SAS version 9.3 software (SAS Institute Inc., Cary, NC, USA).

\section{Results and Discussion}

The individual mean squares for populations and topcross hybrids differed significantly for most of the characters, except ear height, for populations, and grains number, ear diameter, and ear length for top cross hybrids. The landrace populations significantly interacted with their topcross hybrids as to NG, ED, NGR, GM, EM, EL, and GY (Table 1). Machado et al. (2008) mention that crosses between landrace varieties and improved cultivars are an important strategy for the conservation of genetic variability in corn, as well as for obtaining new varieties.

The variation amplitude between the highest and lowest values verified in all evaluated characters evidenced a strong dispersion in the data, which is indicative of the existence of a great genetic variability between the populations and in their topcross hybrids. The variation verified in the landrace populations allows of the possibility of identification of parents that, when combined, would show a greater or lower hybrid vigor (Table 1). Greater amplitudes were observed in the topcross hybrids than in the genitor populations, for most of the characters: NG, PH, ED, NGR, GM, EM, and GY. This result indicates the presence of complementary genes distributed among the parents, which are potentially able to maximize responses in the $F_{1}$ generation, as reported by Bertan et al. (2009). Genetic diversity studies provides an opportunity for the identification of varieties with high-combining capacity, which can assist breeding programs in benefiting from heterosis (Machado et al., 2008).

The landraces Amarelão and Branco Oito Carreiras and the topcross Branco Roxo Indio x 'BRS Planalto' stood out for HGM standard deviations that were higher than the average for this trait (Table 2). Dente de Ouro population and the topcrosses Branco Oito Carreiras $\mathrm{x}$ 'BRS Planalto' and Criolão x 'BRS Planalto' had the highest values for NGR; and the topcross Branco Oito Carreiras x 'BRS Planalto' showed the highest values for GM. 'Dente de Ouro' x 'BRS Planalto' stood out with the highest NG means. These variables are commonly

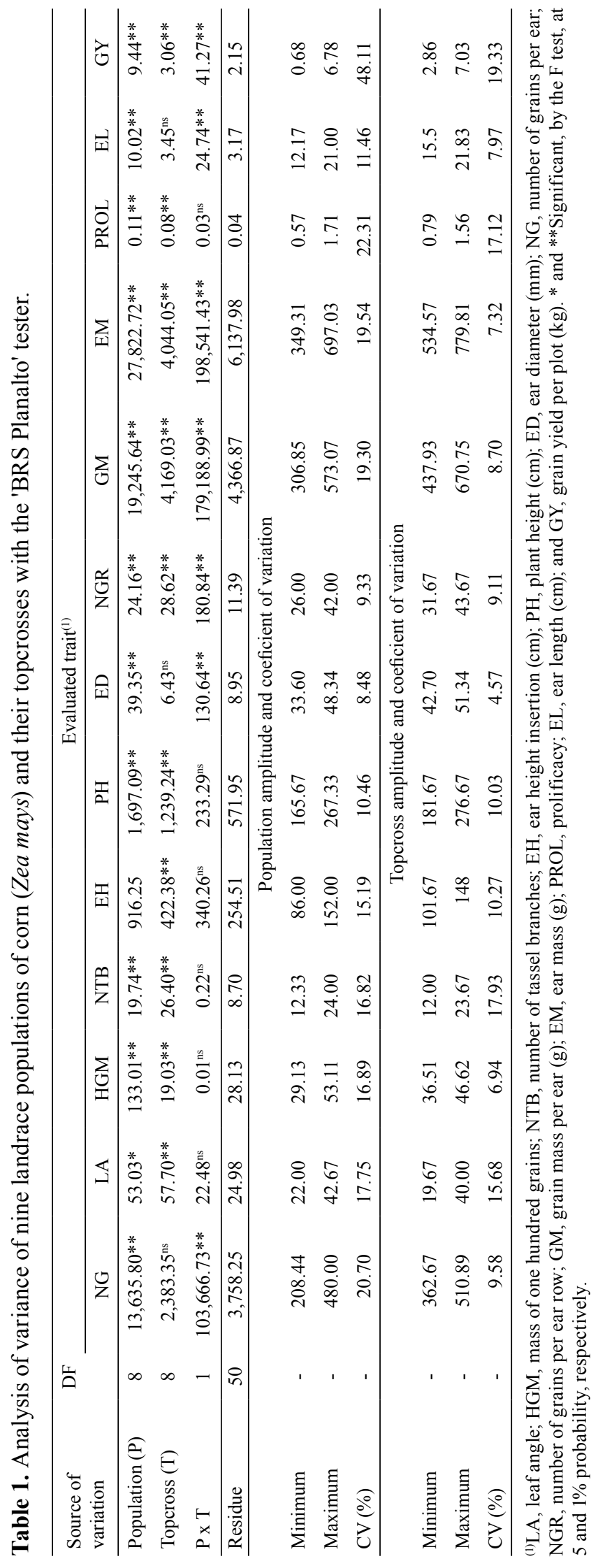

Pesq. agropec. bras., Brasília, v.54, e00265, 2019 DOI: 10.1590/S1678-3921.pab2019.v54.00265 


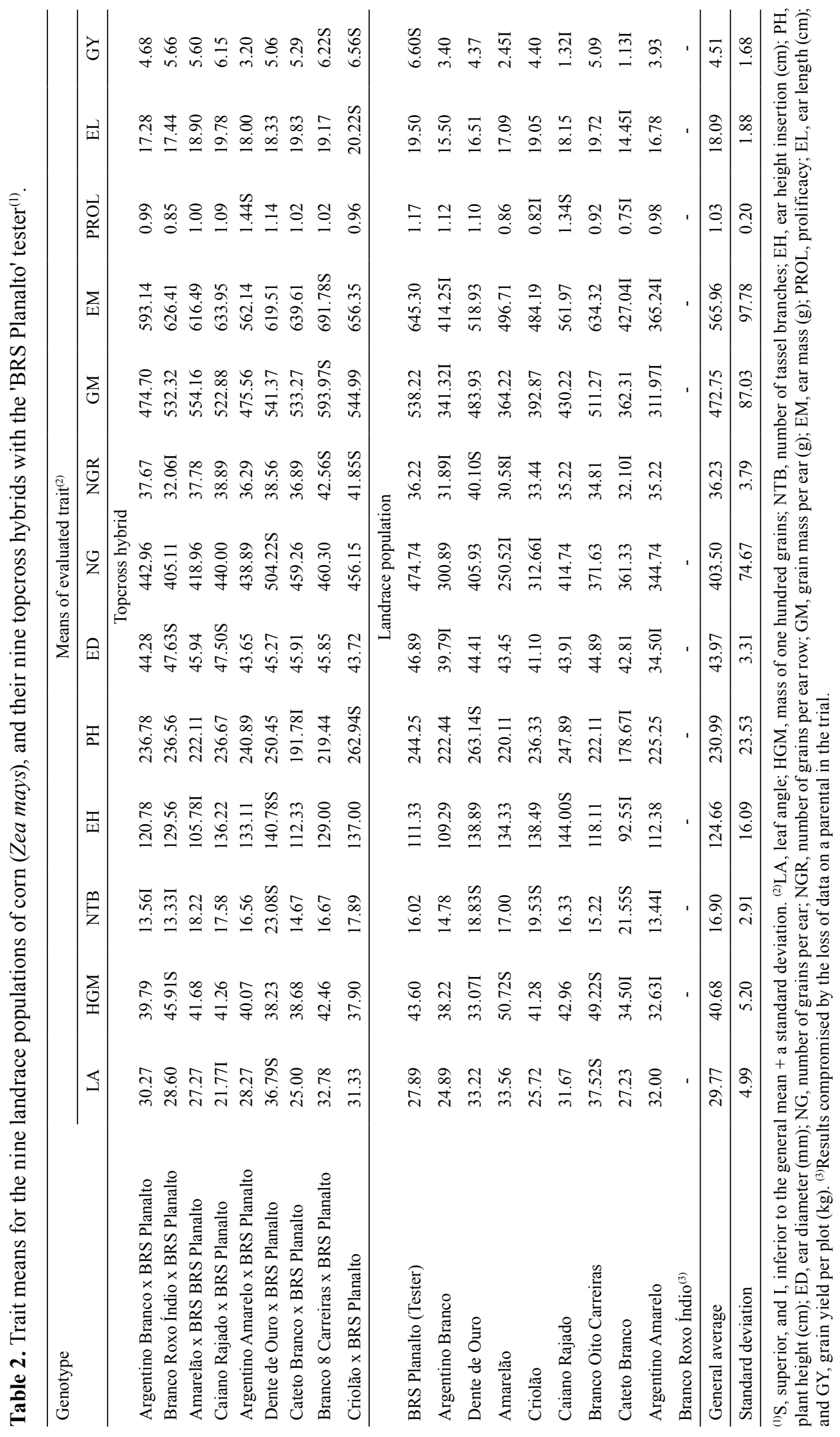


referred to as yield components, which show a high correlation associated with grain yield (Pavan et al., 2011; Khalili et al., 2013; Zeeshan et al., 2013). The topcrosses Branco Roxo Índio x 'BRS Planalto' and Caiano Rajado x 'BRS Planalto' stood out for ED; and Criolão x 'BRS Planalto', for EL. Fancelli \& DouradoNeto (1999) mention that corn breeding programs should consider these traits, as they are positively related to GM. According Nemati et al. (2009), the increase of ear diameter causes an increase in the number of rows per ear, consequently increasing the $\mathrm{NG}$ with a positive reflect on grain yield.

The Caiano Rajado population and Argentino Amarelo x 'BRS Planalto' topcross had the highest means for PROL. Prolific plants generally show a greater tolerance to adverse conditions, due to their ability to develop at least one ear, even under stressing conditions, and more than one when the environmental conditions are favorable. PROL is also related to plant capacity in compensating for grain yield loss when plant stands are below the ideal one (Sangoi et al., 2010).

It should be noted that the Cateto Branco population and the topcrosses Amarelão x 'BRS Planalto' and Cateto Branco x 'BRS Planalto' show lower averages for $\mathrm{EH}$ and $\mathrm{PH}$. These traits are desirable in maize genotypes because they facilitate harvest and make the plants more resistant to lodging.

As to grain yield, the 'BRS Planalto' tester and the topcrosses Branco Oito Carreiras x 'BRS Planalto' and Criolão x 'BRS Planalto' achieved promising results, showing a favorable gene pool for exploitation, to generate populations with high potential yields.

The estimates of heterosis $\left(\mathrm{H}^{2}\right)$ were very variable in the present study (Table 3). Crosses with high heterosis show a high potential for use in breeding programs (Bertan et al., 2009). Caiano Rajado x 'BRS Planalto' $\left(\mathrm{H}^{2}=55.3 \%\right)$, Cateto Branco x 'BRS Planalto' $\left(\mathrm{H}^{2}=36.9 \%\right)$, Amarelão x 'BRS Planalto' $\left(\mathrm{H}^{2}=23.6 \%\right)$, Criolão x 'BRS Planalto' $\left(\mathrm{H}^{2}=19.3 \%\right)$, and Branco Oito Carreiras x 'BRS Planalto' $\left(\mathrm{H}^{2}=6.47 \%\right)$ had the highest estimates of heterosis for grain yield, and are recommended for promoting productivity in studies with landrace maize populations. Moreover, they have distinct genetic backgrounds, which probably resulted in a high frequency of dominant alleles in the hybrid progenies. Paterniani et al. (2008) also showed a high range of heterosis values when studying a set of 36

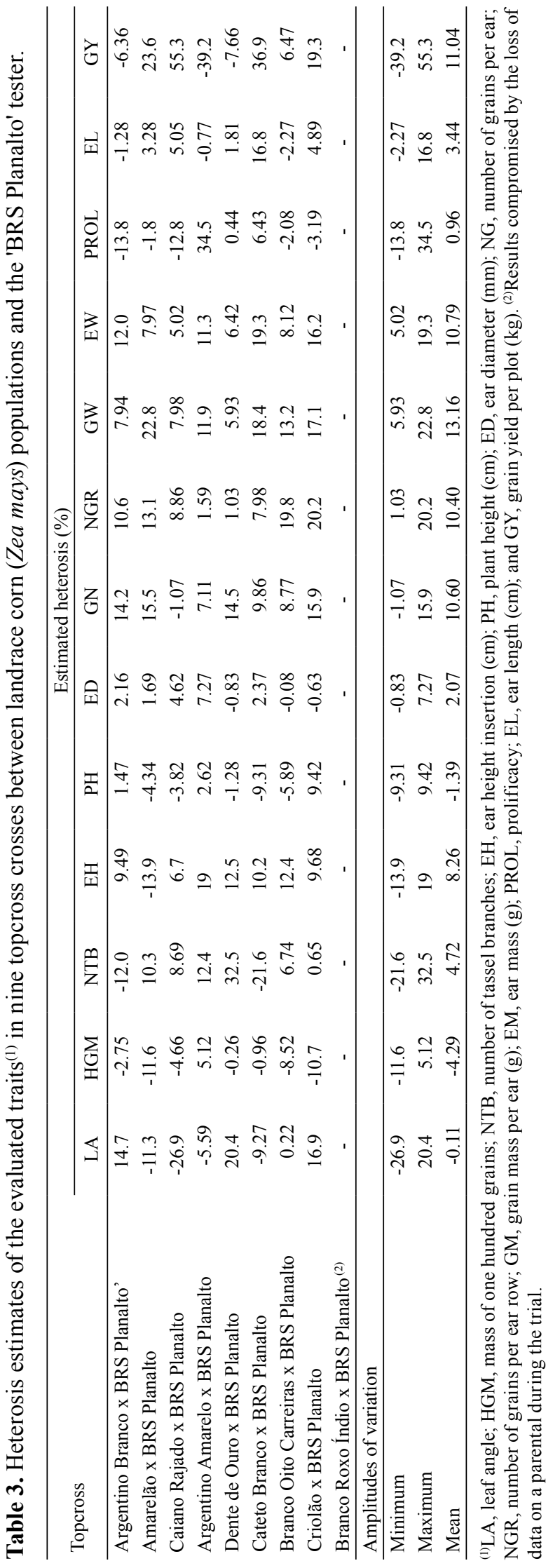

Pesq. agropec. bras., Brasília, v.54, e00265, 2019 DOI: 10.1590/S1678-3921.pab2019.v54.00265 
hybrids, confirming the high-genetic variability among the hybrids and the great diversity among parental lines. Hallauer et al. (2010) presented a compilation of heterosis data for grain yield in corn, with of $20.63 \%$ heterosis mean values, which is higher than the average estimates observed in the present study. However, Ferreira et al. (2009) report that heterosis was evenly distributed among crosses of landrace populations, and did not observe a differentiated heterotic contribution of each variety, which is in disagreement with our results. These findings corroborate the fact that the heterosis estimates depend on and are directly related to the studied populations.

According to Moreira et al. (2009), the generalized distance of Mahalanobis $\left(\mathrm{D}^{2}\right)$ can be used as a powerful tool to estimate the genetic dissimilarity, in order to assist the selection of parents for more promising combinations. For Barili et al. (2011), genotype classifications in heterotic groups can be done with information on genetic dissimilarity. We observed that in the formation of two large groups, according to their genotype mean dissimilarity (Figure 1), the first one was formed by the 'BRS Planalto' tester and the population Branco Oito Carreiras; and the second group, by the populations Argentino Branco, Argentino Amarelo, Caiano Rajado, Dente de Ouro, Amarelão, Criolão, and Cateto Branco.
Heterosis levels were significant and positively correlated only with the genetic distance determined for the ear length trait (Figure 3). However, no significant correlations were observed for the remaining characters, in the investigated populations (Figures 2 and 3). According to Paiva et al. (2002), the combination of genetically distant parents does not always result in expressive heterosis. Paterniani et al. (2008) reported that genetic distances were not correlated with heterosis, and that this trait does not allow inferences on promising crosses in breeding programs. Moreover, these authors reported that higher estimates of genetic dissimilarity did not entail higher values of specific combining ability, and do not correlate with hybrid productivity. Guimarães et al. (2007) investigated the correlation between heterosis estimates and genetic distance between hybrids, determined with molecular markers, and they also observed that the genetic distance does not allow of inferences on the crosses, in corn breeding programs.

The presence of significant associations between heterosis and genetic distance could immensely help the formation of breeding programs, since it allows of previous decision on parents to be used in the crosses (Dias \& Resende, 2001). However, these associations are intrinsic to the gene pool under

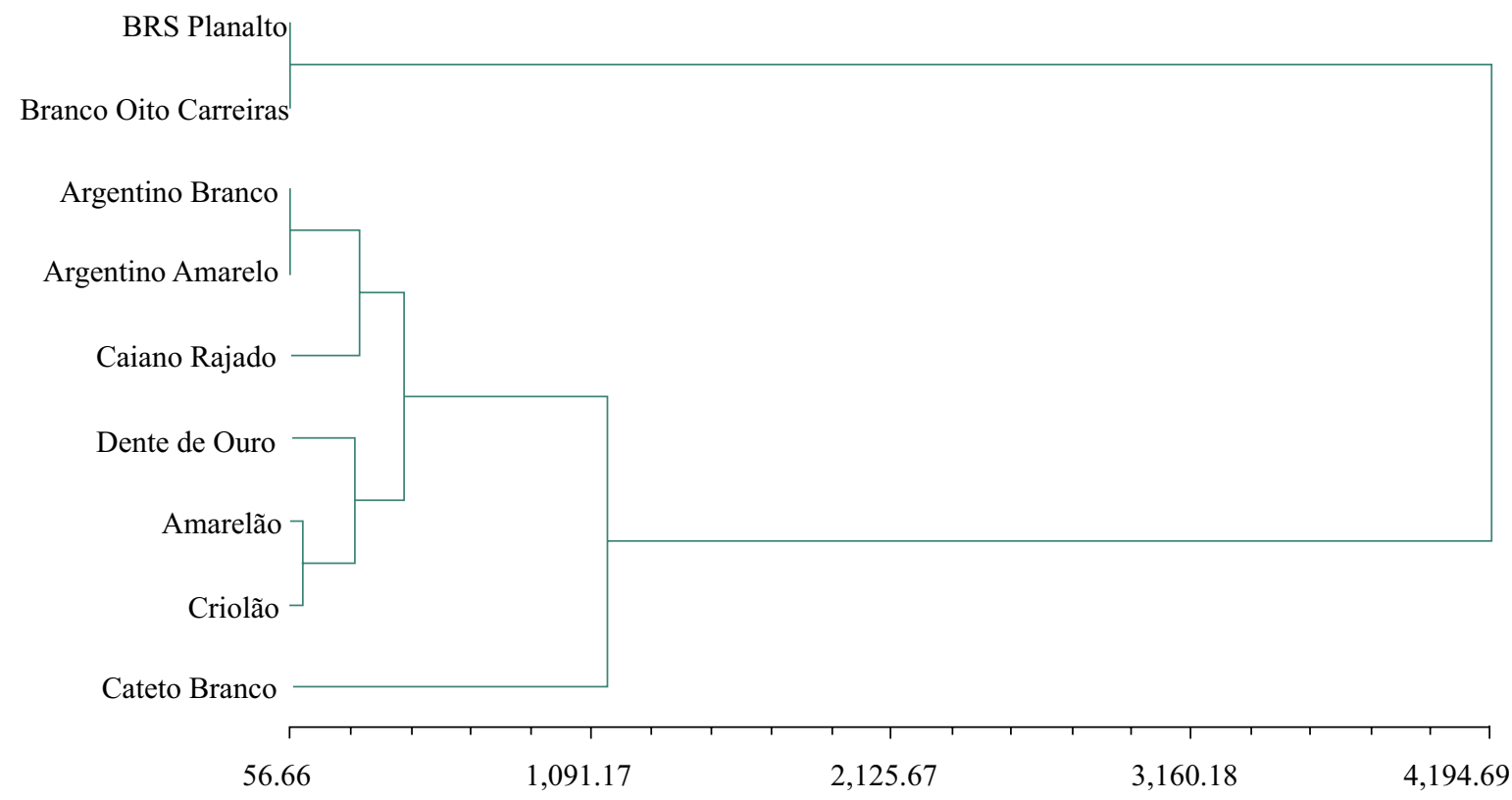

Figure 1. Genetic dissimilarity among the nine corn landrace populations, according to the Mahalanobis generalized distance $\left(\mathrm{D}^{2}\right)$, based on the means obtained for 13 traits. Average dissimilarity, 1,972.30; and cophenetic correlation coefficient, 0.85 . 
investigation. It is important to mention, however, that the absence of significant association between heterosis and genetic distance, as observed in the present study, especially for grain yield, may also be related to nonlinearity between the analyzed parameters (Simon et al., 2012).
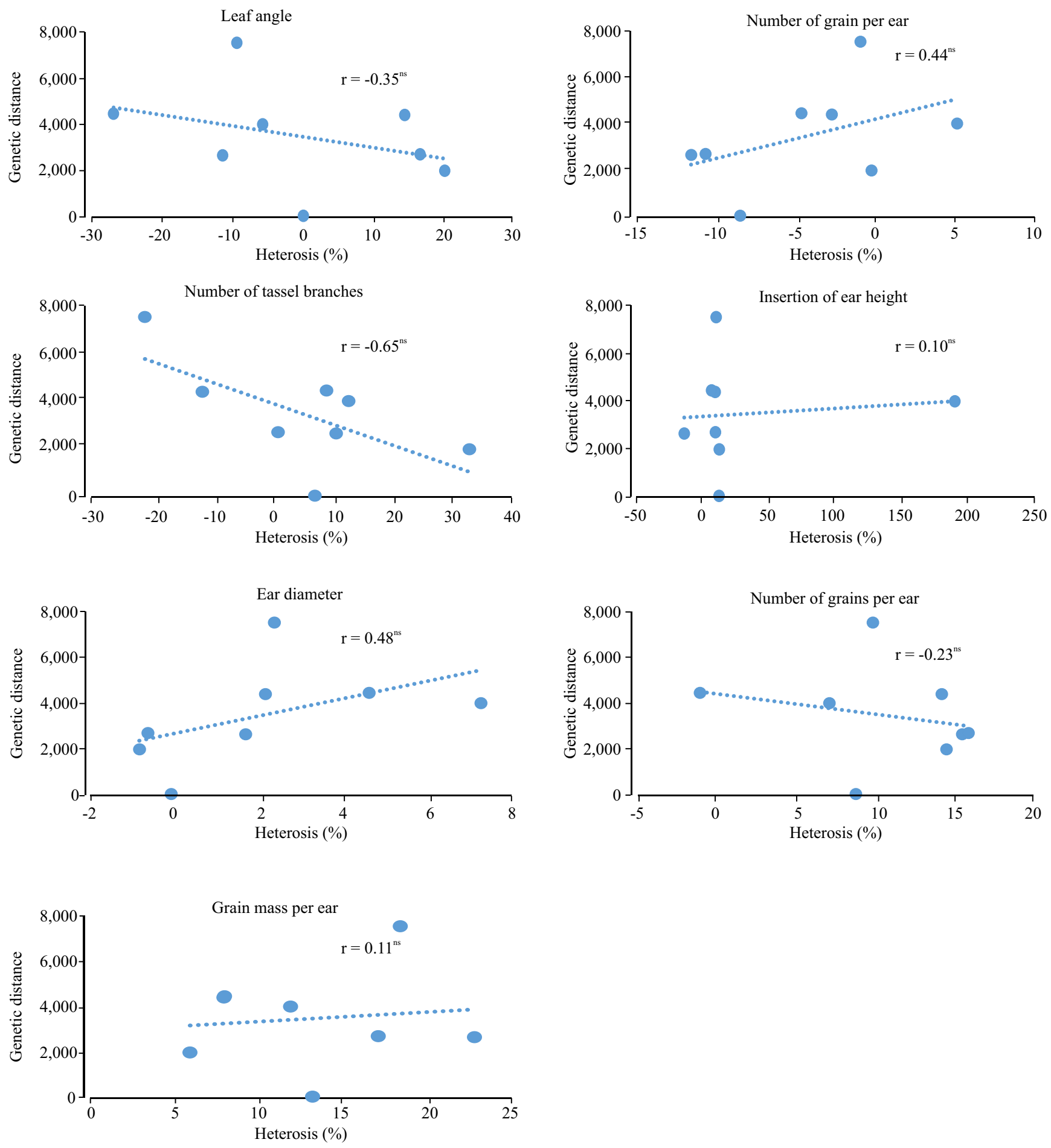

Figure 2. Pearson's correlation coefficient (r) between heterosis, in topcross hybrids, and the genetic distance of the

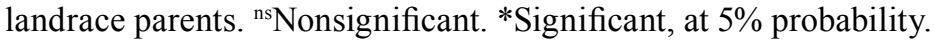



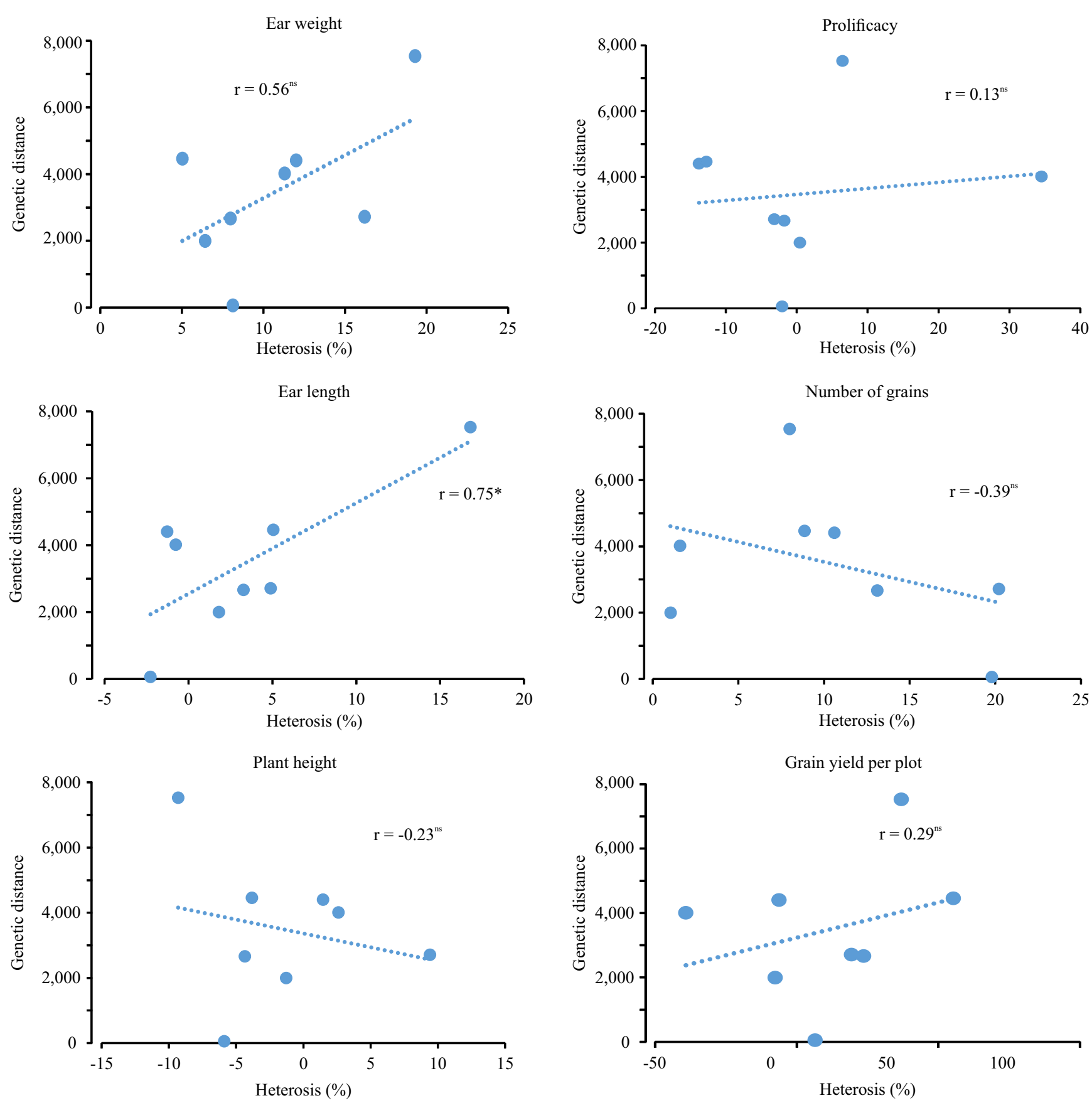

Figure 3. Pearson's correlation coefficient (r) between heterosis, in topcross hybrids, and the genetic distance of the landrace

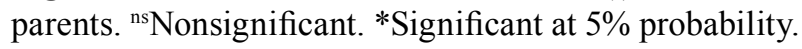

Landrace populations and topcross hybrids with greater per se potential for grain yield were: Branco Oito Carreiras x 'BRS Planalto' and Criolão x 'BRS Planalto'. The first topcross also displays a great performance for grain number per row, grain weight per ear, and ear diameter; and the second one, for grain number per row, and ear length.

\section{Conclusion}

Greater genetic distance estimates between the evaluated landrace populations do not necessarily imply high-heterosis values, but their topcrosses with the 'BRS Planalto' tester show new varieties with high agronomic potential. 


\section{Acknowledgments}

To Coordenação de Aperfeiçoamento de Pessoal de Nível Superior (Capes), to Conselho Nacional de Desenvolvimento Científico e Tecnológico (CNPq), and to Fundação de Amparo à Pesquisa do Estado do Rio Grande do Sul (Fapergs), for funding the project and granting the first author's doctoral fellowship.

\section{References}

ALLARD, R.W. Princípios do melhoramento genético das plantas. São Paulo: Edgard Blucher, 1971. 381p.

ARAÚJO, P.M.; NASS, L.L. Caracterização e avaliação de populações de milho crioulo. Scientia Agricola, v.59, p.589-593, 2002. DOI: https://doi.org/10.1590/S0103-90162002000300027.

BARETTA, D.; NARDINO, M.; CARVALHO, I.R.; DANIELOWSKI, R.; LUCHE, H. de S.; OLIVEIRA, V.F. de; SOUZA, V.Q. de; OLIVEIRA, A.C. de; MAIA, L.C. da. Characterization of dissimilarity among varieties in Brazilian maize germplasm. Australian Journal of Crop Science, v.10, p.1601-1607, 2016. DOI: https://doi.org/10.21475/ajcs.2016.10.12. PNE58.

BARETTA, D.; NARDINO, M.; CARVALHO, I.R.; PELEGRIN, A.J. de; FERRARI, M.; SZARESKI, V.J.; BARROS, W.S.; SOUZA, V.Q. de; OLIVEIRA, A.C. de; MAIA, L.C. da. Estimates of genetic parameters and genotypic values prediction in maize landrace populations by REML/BLUP procedure. Genetics and Molecular Research, v.16, gmr16029715, 2017. DOI: https://doi. org/10.4238/gmr16029715.

BARILI, L.D.; VALE, N.M. do; ARRUDA, B.; TOALDO, D.; ROCHA, F. da; COIMBRA, J.L.M.; BERTOLDO, J.G.; GUIDOLIN, A.F. Escolha de genitores contrastantes para compor o bloco de cruzamentos de genótipos de feijão. Revista Brasileira de Agrociência, v.17, p.303-310, 2011.

BERTAN, I.; CARVALHO, F.I.F. de; OLIVEIRA, A.C. de; SILVA, J.A.G. da; BENIN, G.; HARTWIG, I.; SCHMIDT, D.A.M.; VALÉRIO, I.P.; FONSECA, D.R. da; SILVEIRA, G. da. Efeitos da heterose e endogamia em caracteres de importância agronômica em trigo. Revista Ceres, v.56, p.753-763, 2009.

CARPENTIERI-PÍPOLO, V.; SOUZA, A. de; SILVA, D.A. da; BARRETO, T.P.; GARBUGLIO, D.D.; FERREIRA, J.M. Avaliação de cultivares de milho crioulo em sistema de baixo nível tecnológico. Acta Scientiarum. Agronomy, v.32, p.229233, 2010. DOI: https://doi.org/10.4025/actasciagron.v32i2.430.

CARVALHO, I.R.; PELEGRIN, A.J. de; SZARESKI, V.J.; FERRRARI, M.; ROSA, T.C. da; MARTINS, T.S.; SANTOS, N.L. dos; NARDINO, M.; SOUZA, V.Q. de; OLIVEIRA, A.C. de; MAIA, L.C. da. Diallel and prediction (REML/BLUP) for yield components in intervarietal maize hybrids. Genetics and Molecular Research, v.16, gmr16039734, 2017. DOI: https://doi. org/10.4238/gmr16039734.

COIMBRA, R.R.; MIRANDA, G.V.; CRUZ, C.D.; MELO, A.V. de; ECKERT, F.R. Caracterização e divergência genética de populações de milho resgatadas do Sudeste de Minas Gerais. Revista Ciência Agronômica, v.41, p.159-166, 2010.

CRUZ, C.D.; REGAZZI, A.J.; CARNEIRO, P.C.S. Modelos biométricos aplicados ao melhoramento genético. 4. ed. Viçosa: UFV, 2012. 514p.

DIAS, L.A. dos S.; RESENDE, M.D.V. de. Estratégias e métodos de seleção. In: DIAS, L.A. dos S. (Ed.). Melhoramento genético do cacaueiro. Viçosa: Funape, 2001. p.217-287.

FALCONER, D.S.; MACKAY, T.F.C. Introduction to quantitative genetics. $4^{\text {th }}$ ed. Burnt Mill: Longman, 1996. 464p.

FANCELLI, A.L.; DOURADO-NETO, D. (Org.). Tecnologia da produção de milho. Piracicaba: USP, 1999. 360p.

FERREIRA, J.M.; MOREIRA, R.M.P.; HIDALGO, J.A.F. Capacidade combinatória e heterose em populações de milho crioulo. Ciência Rural, v.39, p.332-339, 2009. DOI: https://doi.org/10.1590/S0103-84782008005000058.

GUIMARÃES, P. de S.; PATERNIANI, M.E.A.G.Z.; LÜDERS, R.R.; SOUZA, A.P. de; LABORDA, P.R.; OLIVEIRA, K.M. Correlação da heterose de híbridos de milho com divergência genética entre linhagens. Pesquisa Agropecuária Brasileira, v.42, p.811-816, 2007. DOI: https://doi.org/10.1590/S0100204 X2007000600007.

HALLAUER, A.R.; CARENA, M.J.; MIRANDA FILHO, J.B. Quantitative genetics in maize breeding. New York: Springer, 2010. 663p. DOI: https://doi.org/10.1007/978-1-4419-0766-0.

KHALILI, M.; NAGHAVI, M.R.; ABOUGHADAREH, A.P.; RAD, H.N. Evaluation of relationships among grain yield and related traits in maize (Zea mays L.) cultivars under drought stress. International Journal of Agronomy and Plant Production, v.4, p.1251-1255, 2013.

MACHADO, A.T.; NASS, L.L.; PACHECO, C.A.P. Cruzamentos intervarietais de milho avaliados em esquema dialélico parcial. Revista Brasileira de Milho e Sorgo, v.7, p.291-394, 2008. DOI: https://doi.org/10.18512/1980-6477/rbms.v7n3p291-304.

MOREIRA, R.M.P.; FERREIRA, J.M.; TAKAHASHI, L.S.A.; VANCONELLOS, M.E.C.; GEUS, L.C.; BOTTI, L. Potencial agronômico e divergência genética entre genótipos de feijão-vagem de crescimento determinado. Semina: Ciências Agrárias, v.30, p.1051-1060, 2009. Supl. 1. DOI: https://doi.org/10.5433/1679-0359.2009v30n4Suplp1051.

NEMATI, A.; SEDGHI, M.; SHARIFI, R.S.; SEIEDI, M.N. Investigation of correlation between traits and path analysis of corn (Zea mays L.) grain yield at the climate of Ardabil region (Northwest Iran). Notulae Botanicae Horti Agrobotanici ClujNapoca, v.37, p.194-198, 2009. DOI: https://doi.org/10.15835/ nbha3713120.

PAIVA, W.O. de. Divergência genética entre linhagens de melão e a heterose de seus híbridos. Horticultura Brasileira, v.20, p.34-37, 2002. DOI: https://doi.org/10.1590/S0102-05362002000100006.

PAIXÃO, S.L.; CAVALCANTE, M.; FERREIRA, P.V.; MADALENA, J.A. da S.; PEREIRA, R.G. Divergência genética e avaliação de populações de milho em diferentes ambientes no estado de Alagoas. Revista Caatinga, v.21, p.191-195, 2008. 
PATERNIANI, M.E.A.G.Z.; GUIMARÃES, P. de S.; LÜDERS, R.R., GALlO, P.B.; SOUZA, A.P. de; LABORDA, P.R.; OLIVEIRA, K.M. Capacidade combinatória, divergência genética entre linhagens de milho e correlação com heterose. Bragantia, v.67, p.639-648, 2008. DOI: https://doi.org/10.1590/S000687052008000300012 .

PAVAN, R.; LOHITHASWA, H.C.; WALI, M.C.; PRAKASH, G.; SHEKARA, B.G. Correlation and path coefficient analysis of grain yield and yield contributing traits in single cross hybrids of maize (Zea mays L.). Electronic Journal of Plant Breeding, v.2, p.253-257, 2011.

ROHLF, F.J. NTSYS-pc: numerical taxonomy and multivariate analysis system. version 2.1. New York: Exeter Software, 2000. $38 \mathrm{p}$.

SANGOI, L.; SCHWEITZER, C.; SCHMITT, A.; PICOLI JR., G.J.; VARGAS, V.P.; VIEIRA, J.; SIEGA, E.; CARNIEL, G. Perfilhamento e prolificidade como características estabilizadoras do rendimento de grãos do milho, em diferentes densidades. Revista Brasileira de Milho e Sorgo, v.9, p.254-265, 2010. DOI: https://doi.org/10.18512/1980-6477/rbms.v9n3p254-265.

SANTOS, H.G. dos; JACOMINE, P.K.T.; ANJOS, L.H.C. dos; OLIVEIRA, V.A. de; OLIVEIRA, J.B. de; COELHO, M.R.;
LUMBRERAS, J.F.; CUNHA, T.J.F. (Ed.). Sistema brasileiro de classificação de solos. 2.ed. Rio de Janeiro: Embrapa Solos, 2006. 306 p.

SIMON, G.A.; KAMADA, T.; MOITEIRO, M. Divergência genética em milho de primeira e segunda safra. Semina: Ciências Agrárias, v.33, p.449-458, 2012. DOI: https://doi.org/10.5433/1679-0359.2012v33n2p449.

SOKAL, R.R.; ROHLF, F.J. The comparison of dendrograms by objective methods. Taxon, v.11, p.33-40, 1962. DOI: https://doi.org/10.2307/1217208.

SUDRÉ, C.P.; RODRIGUES, R.; RIVA, E.M.; KARASAWA, M.; AMARAL JÚNIOR, A.T. do. Divergência genética entre acessos de pimenta e pimentão utilizando técnicas multivariadas. Horticultura Brasileira, v.23, p.22-27, 2005. DOI: https://doi.org/10.1590/S0102-05362005000100005.

ZEESHAN, M.; AHSAN, M.; ARSHAD, W.; ALI, S.; HUSSAIN, M.; KHAN, M. I. Estimate of correlated responses for some polygenic parameters in yellow maize (Zea mays L.) hybrids. International Journal of Advanced Research, v.1, p.24-29, 2013. 